\title{
Studies on Collection and Evaluation of Genetic Variability Available in Amaranthus (Amaranthus spp.) under Chhattisgarh Plain Condition
}

\author{
Yogendra Kumar ${ }^{1 *}$, Rameshwar Prasad ${ }^{2}$ and Puthem Robindro Singh ${ }^{1}$ \\ ${ }^{1}$ Department of Horticulture, College of Agriculture, Gandhi Krishi Vishwavidyalaya, Raipur- \\ 492012, Chhattisgarh, India \\ ${ }^{2}$ Department of Biological Sciences, Sam Higginbottom Institute of Agriculture, Technology \& \\ Sciences, (Deemed-to be University), Allahabad-211007 (U.P.) India \\ *Corresponding author
}

\section{A B S T R A C T}

\section{Keywords}

Amaranthus, genetic variability, GCV, PCV, heritability, genetic advance

Article Info

Accepted:

26 October 2018

Available Online:

10 November 2018
The experiment "studies on collection and evaluation of genetic variability available in Amaranthus under Chhattisgarh plain condition" was conducted at Horticulture Research cum Instructional Farm, Department of Horticulture, Indira Gandhi Krishi Vishwavidyalaya, Raipur (C.G.) during Rabi 2014-15. Twenty five genotypes of Amaranthus were evaluated. High magnitude of phenotypic GCV and PCV was observed for seed yield plot $^{-1}$, followed by test weight, petiole length, number of leaves plant ${ }^{-1}$, stem girth, leaf breadth, leaf length, number of branches plant ${ }^{-1}$ and leaf yield. The heritability estimates recorded to be high for the characters viz. dry matter per cent, fiber content, seed yield plot $^{-1}$, stem girth, test weight, leaf yield plot $^{-1}$, petiole length, leaf breadth and root length, leaf length, number of branches plant ${ }^{-1}$, plant height. Highest estimates of genetic advance as percentage of mean was obtained for characters namely seed yield plot $^{-1}$ and test weight, petiole length, number of leaves plant ${ }^{-1}$, stem girth, leaf breadth.

\section{Introduction}

Amaranthus is one of the important and popular leafy vegetables of india. Amaranthus (Amaranthus spp.), popularly known as "Chaulai". The edible amaranth belongs to the family Amaranthaceae, subfamily Amaranthoideae, and genus Amaranthus. The genus Amaranthus includes 50-60 species, cultivated for leaf as well as for grains and few are wild species. The vegetable amaranth species $(2 \mathrm{n}=34)$ include $A$. tricolor, $A$. dubius, A. lividus, A. blitum, A. hypochondiacus, A. spinosus, and A. viridis, while $(2 \mathrm{n}=32)$ includes $A$. cruentus and $A$. tristis, A. graecizans and A. caudatus. Centres of diversity for amaranth are Central and South America, India and South East Asia with secondary centres of diversity in West and East Africa. Main vegetable type of leaf amaranth is Amaranthus tricolor L., originated in south East Asia, particularly in india. (Rai and Yadav, 2005). 
Amaranthus plants are fast growing, tall, softwooded annuals, extremely variable, erect to spreading with strongly branched tap root. Leaf colour is green or red or with different shades of above. Leaves alternate, long petiolate, simple and entire. The height of mature plants varies between $0.3 \mathrm{~m}$ and $2.5 \mathrm{~m}$, depending on the species, growth habit and environment. Some species have distinct markings on their leaves. Terminal and auxiliary inflorescences occur. Most of the cultivated species are monoecious, wind pollinated, but the grain species with colourful inflorescence are occasionally visited by bees (Khoshoo and Pal, 1970). Amaranth uses the C4 cycle photosynthetic pathway.

Amaranthus is a rich source of nutrients it serves as an alternative source of nutrition for people in developing countries (Prakash and Pal, 1991 and Shukla et al., 2003). Tender stems and leaves contains moisture $(85.70 \%)$, protein $(4.0 \mathrm{~g})$, fat $(0.50 \mathrm{~g})$, carbohydrates $(6.30 \mathrm{~g})$, calcium $(397.0 \mathrm{mg})$, iron $(25.5 \mathrm{mg})$, phosphorus (83.0 mg), vitamin A (9200IU), and vitamin C (99 mg), (Rai and Yadav, 2005). It is also a good source dietery fiber.

Varalakshmi (2004) reported that wide range of variability in Amaranthus plant height (31$81.5 \mathrm{~cm})$, basal lateral branch length (2.3-103 $\mathrm{cm})$, top branch length $(5-58.3 \mathrm{~cm})$, leaf width $(3-12 \mathrm{~cm})$, petiole length $(3-9 \mathrm{~cm})$, inflorescence length $(5-50 \mathrm{~cm})$, inflorescence lateral length $(2.5-32.6 \mathrm{~cm})$, axillary branch length $(0.2-5 \mathrm{~cm})$ and days to $50 \%$ flowering (29-69).

Yadav et al., (2008) reported that the genotypic variability and character association in grain Amaranth genotypes for agronomically useful and yield contributing traits.

India is well-known for its vegetable growing areas. India is the second largest producer of vegetable next to China. India produced 162897 thousand MT of fresh vegetable from 9396 thousand hectare area and 17.3 MT per hectare productivity. (Anon., 2014). In Chhattisgarh, 400024 hectare area is under the vegetable cultivation and production is 5438567 MT out of which 6680 hectare area with production of 62897 MT under leafy vegetables crops (Anon., 2014). In India the major leafy vegetable producing states are Orissa, Uttar Pradesh, Bihar, West Bengal, Karnataka, Kerala, Maharashtra and Chhattisgarh. In Chhattisgarh, it is cultivated in Raigarh, Bilaspur, Raipur and Durg, Rajnandgaon, Balod, Korba, Narayanpur, Baster Kanker, Kawardha and Dhamtari districts.

Parveen et al., (2012) reported high estimate of heritability in the characters of seed yield / plant, length of inflorescence. The highest values of PCV, GCV, heritability and GA shows the character seed weight of 1000 seed, seed yield / plant, and inflorescence / plant.

Pan et al., (2013) studied the estimates of heritability and genetic advance are useful in determining the influence of environment in expression of the characters and the extent to which Improvement is possible after selection.

\section{Materials and Methods}

The present study was conducted in the Horticultural Research Farm, Indira Gandhi Krishi Vishwavidyalaya, Raipur (C.G.) during Rabi season of 2014-15. The seeds of twenty five genotypes of Amaranthus were collected from different part of Chhattisgarh. Field was prepared for planting and was levelled with the help of 'Pata' and ridges were made by tractor drawn ridger at $60 \mathrm{~cm}$ apart in each plot. The experiment was laid out in a Randomized Block Design (RBD) with three replications. The seeds were sown at the depth of 1-2 $\mathrm{cm}$ with a spacing of $20 \mathrm{~cm}$ (Row to 
row) $X 20 \mathrm{~cm}$ (Plant to plant) on $14^{\text {th }}$ November, 2014. Fertilizers Nitrogen, Phosphorus and Potassium were applied for the growth and development of the Amaranthus crop. The field was irrigated at regular interval of 7-10 days. The observations on different growth parameters, leaf and seed yield attributes were recorded on five randomly selected competitive plants of each plot from each replication. Observations were recorded for plant height $(\mathrm{cm})$, number of leaves plant ${ }^{-1}$, number of branches plant ${ }^{-1}$, leaf length plant $^{-1}$, leaf breadth plant $^{-1}$, petiole length plant $^{-1}$, stem girth plant ${ }^{-1}$, root length plant ${ }^{-1}$, leaf yield plot $^{-1}$, leaf yield ha $^{-1}$, seed yield plot $^{-1}$, seed yield ha ${ }^{-1}$, dry matter per cent, test weight and fibre content per cent. Standard statistical procedure were used to for the analysis of variance, genotypic and phenotypic coefficients of variation (Burton, 1952), heritability (Hanson et al., 1956) and genetic advance (Johnson et al., 1955).

\section{Results and Discussion}

\section{Analysis of variance}

Analysis of variance revealed that mean sum of squares due to genotypes found to be highly significant for plant height (52.543), number of leaves plant ${ }^{-1}$ (118.165), seed yield (gm) $\operatorname{plot}^{-1}(1575.659)$, dry matter per cent (39.630), leaf length (6.429), leaf breadth (2.539), petiole length (4.427) while root length (2.044) found significant. This is an indication for existence of the considerable amount of variability in the material studied under the present experiment.

Therefore, the present findings on variance for the yield and its attributes suggest existence of substantial variance for most of the traits in material taken for study. These findings are in general agreement with the findings of Varalakshmi et al., (2004), Shukla et al., (2004), Joshi et al., (2012).

\section{Genetic variability}

High magnitude of phenotypic GCV and PCV was observed for seed yield plot $^{-1} 38.83$ per cent and 39.89 per cent respectively, followed by test weight (30.49 and 31.61 per cent respectively), petiole length (29.13 and 31.89 per cent respectively), number of leaves plant ( 28.67 and 32.13 per cent respectively), stem girth (24.52 and 25.27 per cent, respectively), leaf breadth (23.89 and 28.75 per cent, respectively), Leaf length (23.15 and 28.69 per cent, respectively), number of branches plant $^{-1}$ (19.40 and 24.10 per cent, respectively) and leaf yield (19.23 and 20.18 per cent, respectively). Whereas, the moderate magnitude of GCV along with PCV (15-20 per cent) was observed for dry matter per cent (17.04 and 17.04 per cent, respectively). These findings are in accordance with the findings by Yadav et al., (2008) for seed yield plant ${ }^{-1}$, Aruna (2012) for leaf yield, Akaneme and Anni (2013) for test weight, Khurana et al., (2014) for for number of leaves plant $^{-1}$, Parveen et al., (2014) for seed yield plant ${ }^{-1}$, test weight, Venkatesh et al., (2014) for number of leaves plant $^{-1}$, seed yield, stem girth, test weight, Varalakshmi (2004) for petiole length, Yadav et al., (2008) for seed yield plot $^{-1}$.

The ratio of the genotypic variance to the phenotypic variance or total variance is known as heritability. Estimates of heritability was recorded high for the character dry matter per cent (100.0 per cent) followed by fiber content (98.5 per cent), seed yield plot $^{-1}$ (94.8 per cent), stem girth (94.1 per cent), test weight (93.0 per cent), leaf yield $\operatorname{plot}^{-1}$ (90.9 per cent), petiole length (83.5 per cent), leaf breadth (69.0 per cent) and root length (66.5 per cent), leaf length (65.1 per cent), number of branches plant ${ }^{-1}$ (64.8 per cent) and plant height (64.7 per cent). The present findings on heritability are in accordance with findings reported by the various workers viz. Shukla et al., (2006) for leaf yield, number of branches 
plant $^{-1}$, Yadav et al., (2008) plant height, Hassan et al., (2013) stem girth, yield, parveen varalakshmi et al., (2004) for number of et al., (2012) seed yield plant ${ }^{-1}$, test weight, branches plant ${ }^{-1}$, Akaneme and Anni (2013) Yadav et al., (2008) for leaf breadth, Gerrano for leaf breadth, test weight, leaf length, et al., (2014) for leaf length, test weight.

Table.1a List of Amaranthus genotypes, their source and colour of variety

\begin{tabular}{|c|c|c|c|c|c|}
\hline Genotypes & Farmer's Name & $\begin{array}{l}\text { Collection Place } \\
\text { Village, District }\end{array}$ & Seed colour & $\begin{array}{l}\text { Leaf } \\
\text { colour }\end{array}$ & $\begin{array}{l}\text { Test Wt. } \\
\text { (gm) }\end{array}$ \\
\hline IGA-2013-1 & Shankar lal & Bacharwar, Bilaspur & Reddish Black & Red & 1.2 \\
\hline IGA-2013-2 & Komal Singh & Bacharwar, Bilaspur & Reddish Black & Red & 1.3 \\
\hline IGA-2013-3 & Gopi Singh & Navapara, Bilaspur & Reddish Black & Red & 1.2 \\
\hline IGA-2013-4 & Sanjay Singh & Bhadaura, Bilaspur & Reddish Black & Red & 1.4 \\
\hline IGA-2013-5 & Lalji Singh & Bacharwar, Bilaspur & Reddish Black & Red & 1.2 \\
\hline IGA-2013-6 & Baijnath & Navapara, Bilaspur & Reddish Black & Red & 1.1 \\
\hline IGA-2013-7 & Tijju Bhariya & Bacharwar, Bilaspur & Reddish Black & Red & 1.0 \\
\hline IGA-2013-8 & Bisahu lal & Bacharwar, Bilaspur & Reddish Black & Red & 1.4 \\
\hline IGA-2013-9 & Maika Bhariya & Bacharwar, Bilaspur & Reddish Black & Red & 1.3 \\
\hline IGA-2013-10 & Chetram & Bacharwar, Bilaspur & Reddish Black & Red & 1.3 \\
\hline IGA-2013-11 & Ramesh Yadav & Kethapara, Bilaspur & Reddish Black & Red & 1.9 \\
\hline IGA-2013-12 & Shravan Kumar & Girvar, Bilaspur & Reddish Black & Red & 1.3 \\
\hline IGA-2013-13 & Kirtan Singh & Bacharwar, Bilaspur & Reddish Black & Red & 1.3 \\
\hline IGA-2013-14 & Udhav Nag & Kanker & Reddish Black & Red & 1.3 \\
\hline IGA-2013-15 & Amrit lal & Bacharwar, Bilaspur & Reddish Black & Red & 1.3 \\
\hline IGA-2013-16 & Kanhaiya Lal & Bacharwar, Bilaspur & Dark Black & Red & 1.3 \\
\hline IGA-2013-17 & Bahadur Singh & Bacharwar, Bilaspur & Dark Red & Red & 1.0 \\
\hline IGA-2013-18 & Ajit Singh & Bacharwa, Bilaspur & Dark Red & Red & 1.4 \\
\hline IGA-2013-19 & Santu Singh & Girvar, Bilaspur & Reddish Black & Green & 0.2 \\
\hline IGA-2013-20 & Lakshaman Singh & Patganva, Bilaspur & Dark Black & Green & 0.7 \\
\hline IGA-2013-21 & Munna Singh & Patganva, Bilaspur & Black & Green & 0.7 \\
\hline IGA-2013-22 & Shiv Singh Kanwar & Bacharwar, Bilaspur & Black & Green & 0.6 \\
\hline IGA-2013-23 & Udhav Nag & Kanker & Black & Green & 0.6 \\
\hline IGA-2013-24 & Lakshmi Prasad & Navapara, Bilaspur & Black & Green & 0.7 \\
\hline IGA-2013-25 & Suresh Singh & Navapara, Bilaspur & Black & Green & 0.7 \\
\hline
\end{tabular}


Table.1b Analysis of variance for leaf yield and its components in Amaranthus

\begin{tabular}{|c|c|c|c|c|}
\hline \multirow[t]{4}{*}{ S.No. } & \multirow[t]{4}{*}{ Characters } & \multicolumn{3}{|c|}{ Mean sum of square } \\
\hline & & Replication & Genotypes & Error \\
\hline & & \multicolumn{3}{|c|}{ Degree of freedom } \\
\hline & & 2 & 24 & 48 \\
\hline 1 & Plant height $(\mathrm{cm})$ & 0.169 & $52.543 * *$ & 8.076 \\
\hline 2 & Number of leaves/plant & $22.65 * *$ & $118.165^{* *}$ & 9.287 \\
\hline 3 & Number of branches/plant & 0.0299 & 1.656 & 0.253 \\
\hline 4 & Leaf yield $(\mathrm{kg}) / \mathrm{plot}$ & 0.123 & 0.545 & 0.0176 \\
\hline 5 & Seed yield $(\mathrm{gm}) / \mathrm{plot}$ & $47.171 * *$ & $1575.659 * *$ & 28.294 \\
\hline 6 & Dry matter per cent & 0.00195 & $39.630 * *$ & 0.000352 \\
\hline 7 & Fiber content $(\%)$ & 0.00537 & 1.193 & 0.00587 \\
\hline 8 & Root length (cm) & 0.0837 & $2.044 *$ & 0.293 \\
\hline 9 & Test weight (gm) & 0.00648 & 0.391 & 0.00954 \\
\hline 10 & Leaf length $(\mathrm{cm})$ & $5.609 * *$ & $6.429 * *$ & 0.974 \\
\hline 11 & Leaf breadth $(\mathrm{cm})$ & 1.469 & $2.539 * *$ & 0.330 \\
\hline 12 & Petiole length $(\mathrm{cm})$ & 2.001 & $4.427 * *$ & 0.274 \\
\hline 13 & Stem girth $(\mathrm{cm})$ & 0.0905 & 1.448 & 0.0294 \\
\hline
\end{tabular}

*Significant at $5 \%$; **Significant at $1 \%$

Table.2 Estimates of genetic parameters of variation for leaf yield and its components in Amaranthu

\begin{tabular}{|c|c|c|c|c|c|c|c|c|c|}
\hline \multirow[t]{2}{*}{ S.N. } & \multirow[t]{2}{*}{ Characters } & \multirow[t]{2}{*}{ Mean } & \multicolumn{2}{|c|}{ Range } & \multicolumn{2}{|c|}{$\begin{array}{c}\text { Coeeicient of Variation } \\
(\%)\end{array}$} & \multirow[t]{2}{*}{$\begin{array}{l}\text { Heritability } \\
\quad\left(h^{2} b\right) \%\end{array}$} & \multirow{2}{*}{$\begin{array}{c}\text { Genetic } \\
\text { Advances } \\
\mathbf{K}=\mathbf{2 . 0 6}\end{array}$} & \multirow{2}{*}{$\begin{array}{c}\text { Genetic } \\
\text { Advances } \\
\text { as \% of } \\
\text { mean }\end{array}$} \\
\hline & & & minimum & maximum & Genotypic & Phynotypic & & & \\
\hline 1 & Plant height (cm) & 26.324 & 17.18 & 34.90 & 14.62 & 18.18 & 64.7 & 6.38 & 24.24 \\
\hline 2 & Number of leaves/plant & 21.012 & 12.97 & 33.63 & 28.67 & 32.13 & 79.6 & 11.07 & 52.68 \\
\hline 3 & Number of branches/plant & 3.524 & 2.13 & 4.67 & 19.40 & 24.10 & 64.8 & 1.13 & 32.10 \\
\hline 4 & Leaf yield (kg)/plot & 2.181 & 1.67 & 2.90 & 19.23 & 20.18 & 90.9 & 0.82 & 37.61 \\
\hline 5 & Seed yield $(\mathrm{gm}) / \mathrm{plot}$ & 58.480 & 20.78 & 90.20 & 38.83 & 39.89 & 94.8 & 45.55 & 77.88 \\
\hline 6 & Dry matter per cent & 21.328 & 15.37 & 29.79 & 17.04 & 17.04 & 100.0 & 7.49 & 35.13 \\
\hline 7 & Fiber content (\%) & 7.364 & 5.97 & 8.25 & 8.54 & 8.61 & 98.5 & 1.29 & 17.52 \\
\hline 8 & Root length (cm) & 7.858 & 6.00 & 9.67 & 9.72 & 11.92 & 66.5 & 1.28 & 16.30 \\
\hline 9 & Test weight (gm) & 1.170 & 0.33 & 1.83 & 30.49 & 31.61 & 93.0 & 0.71 & 60.68 \\
\hline 10 & Leaf length (cm) & 5.824 & 3.25 & 8.07 & 23.15 & 28.69 & 65.1 & 2.24 & 38.48 \\
\hline 11 & Leaf breadth (cm) & 3.592 & 1.77 & 4.87 & 23.89 & 28.75 & 69.0 & 1.47 & 40.94 \\
\hline 12 & Petiole length (cm) & 4.038 & 1.97 & 6.14 & 29.13 & 31.89 & 83.5 & 2.21 & 54.83 \\
\hline 13 & Stem girth $(\mathrm{cm})$ & 2.805 & 1.60 & 3.93 & 24.52 & 25.27 & 94.1 & 1.37 & 48.92 \\
\hline
\end{tabular}


Fig.1 Graphical presentation of GCV and PCV for leaf yield and its components of Amaranthus

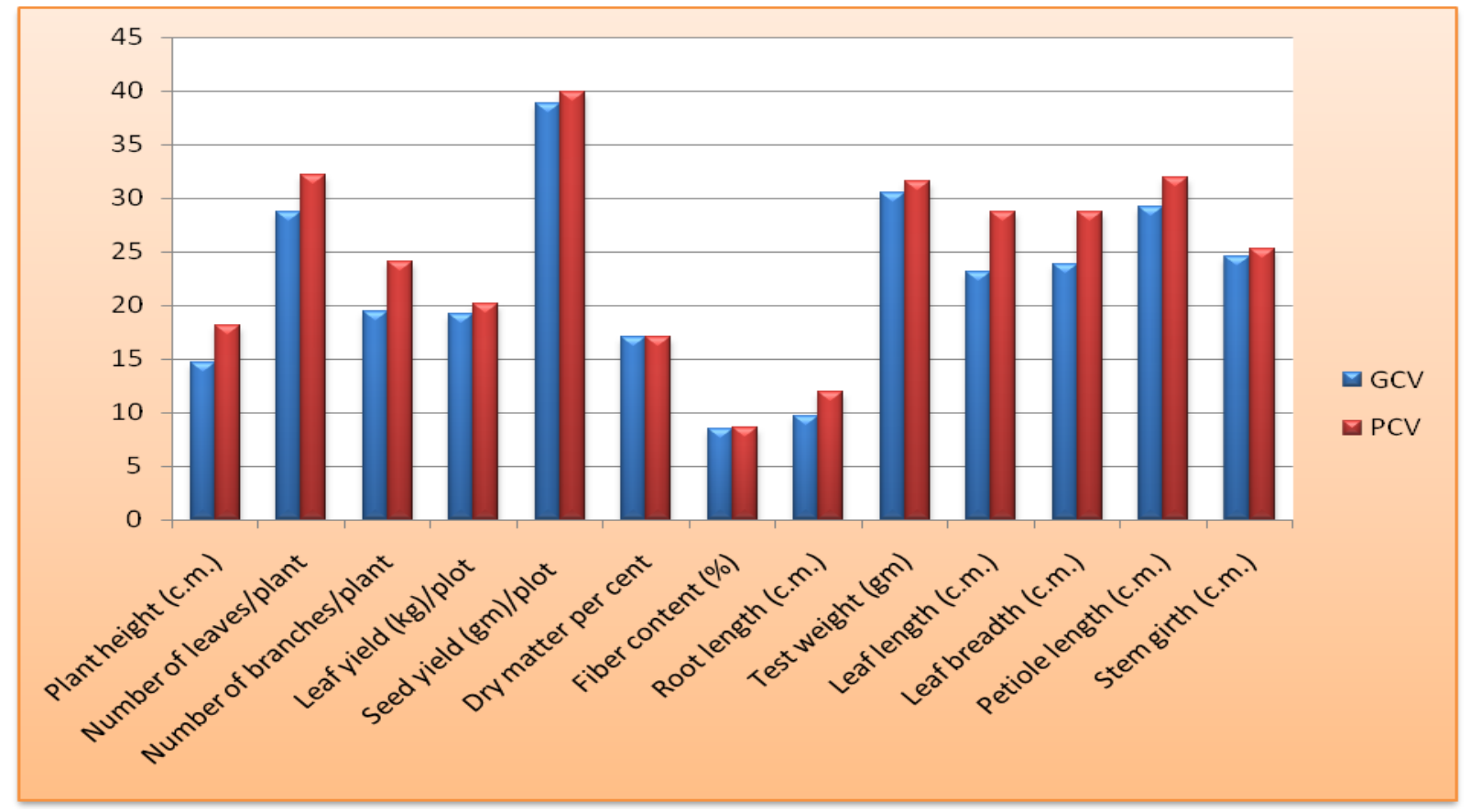

Fig.2-Graphical presentation of heritability $\%$ and genetic advance per cent of mean for leaf yield and its components of Amaranthus

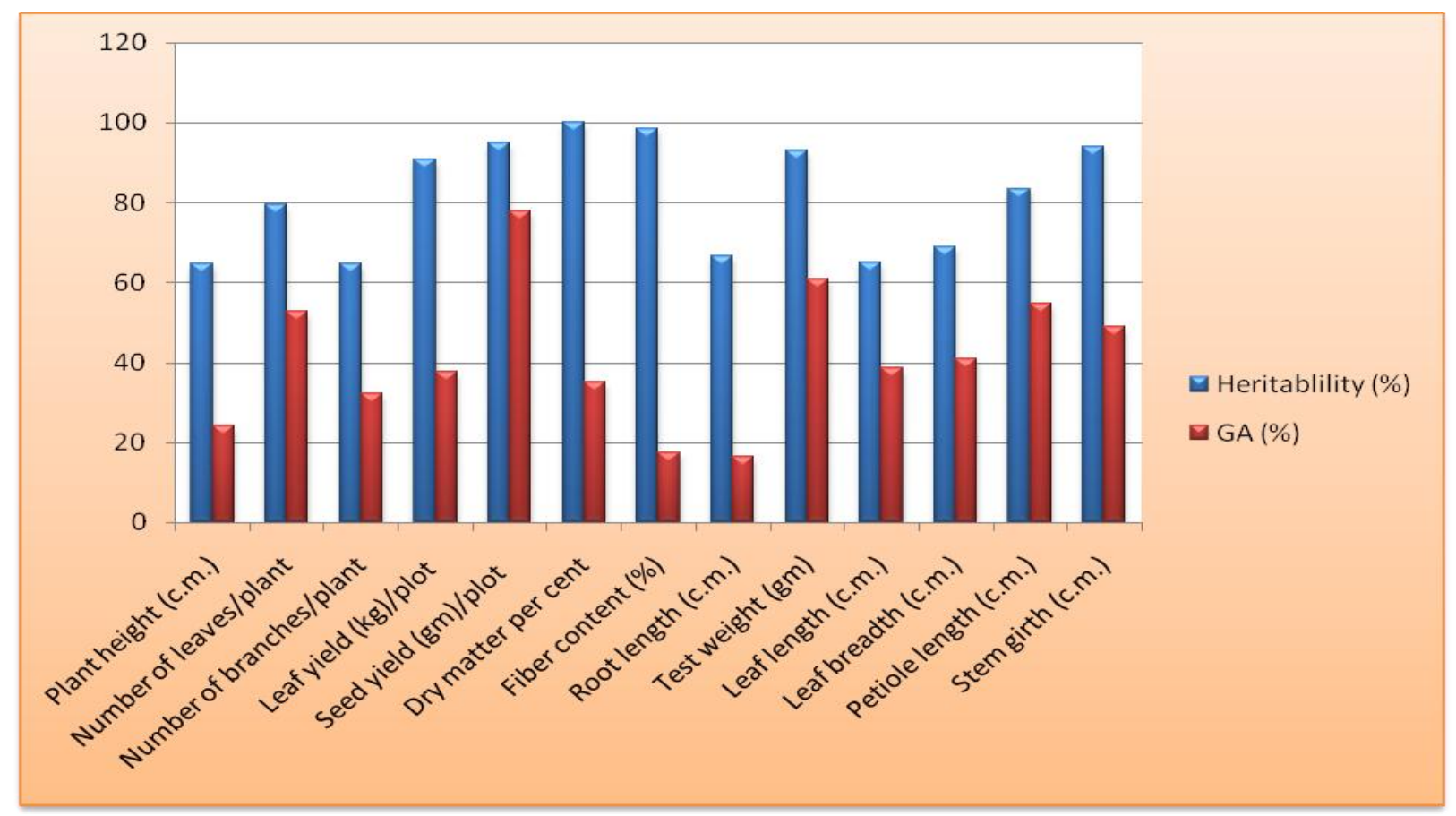


Genetic advance is important to find out the genetic gains likely to be achieved in the next generation. These are classified as high $(>40$ per cent), medium ( 25 to 40 per cent) and low ( $<25$ per cent). In the present study highest estimates of genetic advance as percentage of mean was obtained for characters namely seed yield plot $^{-1}$ (77.88 per cent) and test weight (60.68 per cent), petiole length (54.83 per cent), number of leaves plant ${ }^{-1}$ (52.68 per cent), stem girth (48.92 per cent), leaf breadth (40.94 per cent). The high value of genetic advance for these traits showed that these characters are governed by additive genes and selection will be rewarding for the further improvement of such traits. The moderate genetic advance observed in characters namely leaf length (38.48 per cent), leaf yield plot $^{-1}$ (37.61 per cent), dry matter per cent (35.13 per cent), number of branches plant ${ }^{-1}$ (32.10 per cent).

In the present study, high heritability estimates coupled with high genetic advance was recorded for the traits, seed yield plot $^{-1}$, test weight, petiole length, number of leaves plant $^{-1}$, stem girth and leaf breadth. These findings are in accordance with the findings by Shukla et al., (2006) for leaf length, leaf yield plot $^{-1}$, Akaneme and Anni (2013) for test weight, leaf length, Parveen et al., (2012) seed yield plot $^{-1}$, test weight, Gerrano et al., (2014) for test weight, number of leaves plant $^{-1}$.

\section{References}

Anonymous, 2014. Indian Horticulture Database 2014. National Horticulture Board, Ministry of Agriculture, Government of India, Gurgaon, India. Website: www.nhb.gov.in

Anonymous, 2014. Directorate of Horticulture, C.G. Government, Raipur p.6

Akaneme, F.I,. and Ani, G.O., 2013.
Morphological Assessment of Genetic Variability among Accessions of Amaranthus hybridus. The Sci. Tech., J. of Sci. and Tech., 2(2): 26-30.

Aruna, P. 2012. Correlation and path analysis in amaranthus. J. of Agric. Sci. 4(3): 5054

Burton, G.W. 1952. Quantitative inheritance in grasses. Proc. 6th Int. Gr. Ld. Cong., 1: 277- 283.

Gerrano, A. S. Jansen, W. S., Rensburg V. and Adebola,P. O. 2014. Genetic diversity of Amaranthus species in South Africa. Plant Biosystems, 148(4): 635-644.

Hanson, W. D., Robinson, H. F. and Comstock, R. E. 1956. Biometrical studies of yield in segregating population of Korean lespedeza. Agron. J., 48: 268-272. genotypes. Veg. Sci. 35(1): 81-83.

Hasan, M., Akther, C. A. and Raihan,M. S. 2013. Genetic Variability, Correlation and Path Analysis in Stem Amaranth (Amaranthus tricolor L.) Genotypes. Bangladesh J. Pl. Breed. Genet. 25(1): 17-23.

Johnson, H.W., Robinson, H.F. and Comstock, R.E. 1955. Estimates of genetic environmental variability in soybean. Agron. J., 47: 314-318.

Joshi, V., Vijaya, M., Sireesha, K. and Latha, P. M. 2012. Characterization and preliminary evaluation of Vegetable amaranth (Amaranthus spp.). Annals of Biological Research, 3 (2):1014-1019.

Khoshoo, T.N. and Pal, M., 1970. Chromosomes Today, 3: 359-267.

Khurana, D.S., Singh, J. and Kaur, B. 2014. Genetic variability, correlation and path coefficient anlaysis in Amaranthus, Veg. Sci., 40 (2): 238-240.

Pan, R.S., Singh, A.K., Kumar, S. and Mathura R.I. 2013. Genetic variation and Character association in vegetable Amaranth (Amaranthus tricolor 1.). The 
Sci. Tech, J. of Sci. Tech. 2(2): 26-30.

Parveen, M., Chattopadhyay, N. C. and Tah, J. 2012. Biometric evaluation of genotypic variability and genetic advance in amaranth cultivars. J. of agric. Sci. vol. 4, No. 3

Parveen, M., Chattopadhyay, N. C., Tah J. 2014. Strategy of biometric evaluation of vegetative yield attributes of amaranth cultivars. Bioscience Discovery, 5(1):70-73.

Prakash, D. and M. Pal. 1991. Nutritional and anti nutritional composition of vegetable and grain amaranth leaves. J. Sci. Food Agric., 57: 573-583.

Rai, N. and Yadav, D.S., 2005. Advances in vegetable production. Researchco Book Centre New Delhi, 530-531.

Shukla, S., Bhargava, A., Chatterjee, A., Srivastava A. and Singh, S.P. 2006. Genotypic

variability in vegetable amaranth (Amaranthus tricolor L.) for foliage yield and its contributing traits over successive cuttings and years. Division of Genetics and Plant Breeding, National Botanical Research Institute, 151: 103-110.

Shukla, S., Bhargava, A., Chatterjee A. and
Singh, S.P. 2004a. Estimates of genetic parameters to determine variability for foliage yield and its different quantitative and qualitative traits in vegetable amaranth (A. tricolor). J. Genet. Breed., 58: 169-176.

Shukla, S., Pandey, V., Pachauri, G., Dixit, B.S., Banerji R. and Singh, S.P. 2003. Nutritional contents of different foliage cuttings of vegetable amaranth. Pl. Food Hum. Nutr., 58:1-8.

Yadav, R., Rana, J. C. And Ranjan, J. K. 2008. Analysis of variability parameters for morphological and agronomic traits in grain amaranth (amaranthus $\mathrm{sp}$ ) genotypes. NBPGR, Indian Institute of vege. Res., Veg. Sci. 35(1): 81-83

Varalakshmi, B. 2004. Characterization and preliminary evaluation of vegetable Amaranth (Amaranthus spp.) germplasm. Pl. Gene. Reso. Newsletter, (137):55-57.

Venkatesh, L., Murthy, N., Manjappa and Nehru, S. D. 2014. Character association and path co-efficient analysis for various traits in grain amaranth (Amaranthus spp.). Asian J. of Bio Sci., 9: 97-100.

\section{How to cite this article:}

Yogendra Kumar, Rameshwar Prasad and Puthem Robindro Singh. 2018. Studies on Collection and Evaluation of Genetic Variability Available in Amaranthus (Amaranthus spp.) under Chhattisgarh Plain Condition. Int.J.Curr.Microbiol.App.Sci. 7(11): 3540-3547. doi: https://doi.org/10.20546/ijcmas.2018.711.406 